\title{
Antiallergic effects of caffeic acid in blomia tropicalis murine model of experimental asthma
}

\begin{abstract}
Background: Atopic asthma is a chronic airway inflammatory disorder, which is characterized by reversible airway obstruction, airway hyper responsiveness and production of Th2-dominated response with the production of cytokines IL-4, IL-5 and IL-13. The most common drugs used to treat allergic respiratory diseases, control their symptoms, but also induce long-term side effects. Therefore, in order to mitigate these effects, new treatments with alternative drugs must be pursued to improve asthma control. Among several compounds investigated by the scientific community, caffeic acid (CA), a phenolic acid has shown important biological properties, such as antioxidant and anti-inflammatory. In this study we investigated the antiallergic effects of caffeic acid on inflammatory cytokines, in vitro, and in a murine model of experimental asthma induced by the Blomia tropicalis extract (Bt).
\end{abstract}

Methods: We measured the concentration of cytokines (IL-4, IL-5 and IL-13) on spleen cell culture supernatants in vitro, using 25,50 or $100 \mu \mathrm{M}$ of CA. For in vivo experiments, AJ mice were sensitized $(100 \mu \mathrm{g} /$ animal s.c) and challenged $(10 \mu \mathrm{g} /$ animal i.n) with Bt. Sensitized A/J mice were treated or not with CA $(10,100$ or $200 \mathrm{mg} / \mathrm{Kg}$ ) or with $3 \mathrm{mg} / \mathrm{kg}$ of Dexametazone (Dex) and the following parameters were analyzed: number of total cells in bronchoalveolar lavage (BAL); eosinophil peroxidase activity (EPO) in BAL; serum level of specific IgE, IgG1 and IgG2a; and histopathological changes in the lungs.

Results: The CA oral treatment caused a reduction in total number of cells in BAL, EPO in lungs, serum level of specific IgG1 and histopathological changes showed attenuate allergic inflammation in the lungs. Additionally, we observed a significant decrease of Th2-type cytokines (IL-4, IL-5 and IL-13) on spleen cell culture supernatants.

Conclusion: These results suggest that oral treatment with caffeic acid could be a promising alternative treatment for bronchial asthma.

Keywords: caffeic acid, polyphenols, allergy, experimental asthma, blomia tropicalis, inflammation, anti asthmatic drugs
Volume I Issue 4 - 2014

Tamires Cana Brasi Carneiro,' Ryan Santos Costa,' Norma Vilany Queiroz Carneiro,' Ana Tereza Cerqueira-Lima,' Tatiane Oliveira,' Keina Dourado,' Darizy Flávia Silva,'Valdirene Leão Carneiro, ${ }^{2}$ Neuza Maria AlcântaraNeves,' Lain Carlos Pontes-de-Carvalho, Camila Alexandrina Figueiredo'

'Instituto de Ciências da Saúde, Universidade Federal da Bahia, Brazil

${ }^{2}$ Departamento de Ciências da Vida, Universidade do Estado da Bahia, Brazil

${ }^{3}$ Centro de Pesquisas Gonçalo Moniz, Fundação Oswaldo Cruz, Brazil

Correspondence: Camila Alexandrina Figueiredo,

Departamento de Biorregulação, Instituto de Cisncias da Saúde, Universidade Federal da Bahia, Campus do Canela, CEP 4 I I I0 I00, Salvador, Brazil, Tel +557I 32838948, Fax +557I32838948, Email cavfigueiredo@gmail.com

Received: November 12, 2014 | Published: November 27, 2014
Abbreviations: BAL, bronchoalveolar lavage; BSA, bovine serum albumin; Bt, blomia tropicalis; CA, caffeic acid; Dex, dexametazone; ELISA, enzyme-linked immunosorbent assay; EPO, eosinophil peroxidase; FCS, fetal calf serum; Ig, immunoglobulin; IN, intranasal route; IL, interleukin; PWM, pokeweed mitogen; RT, room temperature; $\mathrm{SC}$, subcutaneous route; $\mathrm{VO}$, oral route

\section{Introduction}

Asthma is a common allergic inflammatory disease on the respiratory tract ${ }^{1}$ which may affect all age groups, in particular, kids where the prevalence ranges from $14.1 \%$ for $13-14$-year age group and $11.7 \%$ for $6-7$-year old ${ }^{2}$ being the leading cause of hospitalizations among young children. ${ }^{3}$ Allergic asthma is characterized by a high immunoglobulin E ( $\mathrm{IgE}$ ) production by B cells, intense cell influx into the lungs, where eosinophils are the most important cell type found, increased mucus production, airway hyperresponsiveness (AHR), reversible airway obstruction, and lung tissue remodeling. ${ }^{4,5}$ Mites are a major cause of allergy all over the world, but there are geographic differences in distribution of mites and in the prevalence of mite sensitization, ${ }^{6}$ and in tropical and subtropical areas Blomia tropicalis allergens are among the most frequent sensitizer agents. ${ }^{7}$ Exposure to $\mathrm{B}$. tropicalis allergens in the airway produces a Th2-dominated response by recruiting and activating inflammatory cells including eosinophils, and increases the levels of IL-4, IL-5 and IL-13. ${ }^{8}$ The occurrence of these markers is commonly associated with allergic asthma pathophysiology. ${ }^{9}$

Corticosteroids, b2-adrenergic agonists, phosphodiesterase (PDE) inhibitors and leukotriene receptor antagonists are the most common drugs used to treat asthma and other allergic respiratory diseases. These drugs control the illness symptoms but also induce longterm side effects, such as osteoporosis, growth stunting in children, hyperglycemia and hypokalemia. ${ }^{10}$ Therefore, new alternative treatments are needed to improve these diseases control.

Natural phenolic compounds are present in considerable amounts in the human diet. Phenolic acids can be classified into two groups according to the structure attached to the phenol ring:

\section{i. hydroxybenzoic acids \\ ii. hydroxycinnamic acids. ${ }^{11}$}

The caffeic acid (CA) is one of the major representative hydroxycinnamics acids widely distributed in plant tissues, present in foods such as fruits, spices, vegetables, wine, olive oil, and coffee. ${ }^{12}$ 
Some biological activities ofCA have been reported in the literature, such as: antioxidant, ${ }^{13}$ anticolitic, ${ }^{14,15}$ antinociceptive ${ }^{16}$ and analgesic. ${ }^{17}$ Furthermore, the CA seems to have antiinflammatory effects due to the suppression of proinflammatory cytokines production such as IL$1 b$, IL-6 and TNF- $\alpha,{ }^{18}$ and also through the inhibition of vascular permeability, possibly, by an inhibition of histamine release from mast cells ${ }^{19}$ and leukotriene biosynthesis inhibition. ${ }^{20}$ Some authors also suggest that this molecule may suppress the activation of transcription factors such as NF-kB and inhibit the intracellular signaling cascades such as MAPK. ${ }^{21-23}$ Regarding to its antiallergic activity, we have recently found that the specie Ocimum gratissimum $(\mathrm{Og})$ has an important immune modulatory effect on experimental asthma model and one of the polyphenol compounds found on O. gratissimum is the CA. ${ }^{24}$ However, few studies were found exploring the anti allergic potential of CA.

Considering the lack of effective drug to treat allergic asthma and based on the possible antiallergic effect of CA, we investigated in this paper the effects of caffeic acid in an experimental model of respiratory allergy to Blomia tropicalis, in order to further explore its possible effect as antiallergic agent for the treatment of allergic diseases.

\section{Materials and methods}

\section{Animals}

Male AJ mice $(25-30 \mathrm{~g})$ were used throughout the study. Animals were maintained with free access to food and water. They were obtained from the animal facilities of the Fundação Oswaldo Cruz, Bahia, Brazil. Groups of 5 animals were used in each experiment. All the experimental procedures were approved by the Ethical Committee for Use of Experimental Animals of the Faculdade de Odontologia, Universidade Federal da Bahia, and Brazil and conducted according to international standards.

\section{Blomia tropicalis extract}

The B. tropicalis mites were cultivated in a fish food-containing standardized environment, purified with saturated $\mathrm{NaCl}$ and filtering in a $20 \mathrm{Mm}$ pore size metal sieve, and lysed in $0.15 \mathrm{M}$ phosphate-buffered saline, pH 7.4 (PBS), in a blender (51BL30 - Waring Commercial, Torrington, CO, USA). After several centrifugations with ether $(9000 \mathrm{~g}$ for $10 \mathrm{~min}$ ), for removal of lipids, the protein content was determined by Lowry's method ${ }^{25}$ and the extract was stored at $-20^{\circ} \mathrm{C}$ until use. The $\mathrm{B}$. tropicalis extract $(\mathrm{Bt})$ was standardized by determining the Blo t 5 allergen concentration using a commercial capture ELISA (INDOOR Biotechnologies, Charlottesville, VI, USA). All used Bt batches contained 30-40ng of this allergen per $\mu \mathrm{g}$ of extra.

\section{Sensitization and challenge with Blomia tropicalis antigen}

The murine model of respiratory allergy was induced as we previously described. ${ }^{8}$ Briefly, A/J mice $(n=5)$ were initially sensitized

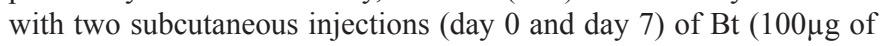
protein), adsorbed to $4 \mathrm{mg} / \mathrm{mL}$ of $\mathrm{Al}(\mathrm{OH}) 3$ in saline (Figure 1). Twentyfour hours after the last subcutaneous injection, the animals received three intranasal boosters/challenges with Bt $(10 \mu \mathrm{g} /$ instilation) every other day (Figure 1). A negative control group received saline in both sensitization and challenge procedures. Twenty-four hours after the last challenge, the animals were euthanized with intraperitoneal injections of xilazine and ketamine (40 mg/kg/body weight).

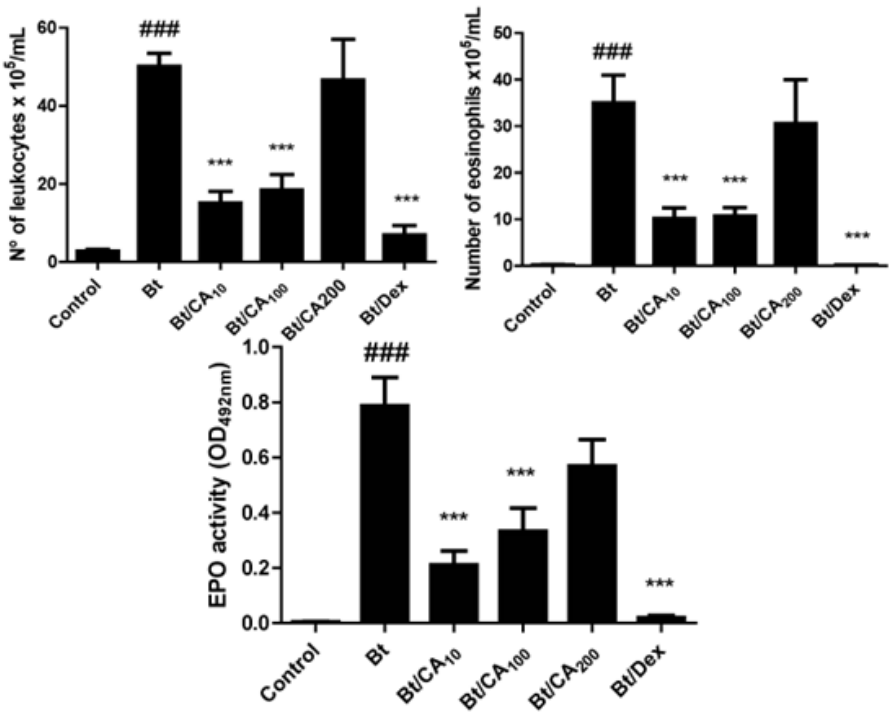

Figure I Effect of treatment with caffeic acid (CA) in the numbers of inflammatory cells, mainly eosinophils, in the airways of Blomia tropicalis extract $(\mathrm{Bt})$-immunized and challenged mice. $(\mathrm{A})$ number of leukocytes in the bronchoalveolar lavage (BAL) $(B)$ number of eosinophils in the BAL (C) levels of EPO in the BAL;. Groups: Control, vehicle-treated animals; Bt, Bt-sensitized and challenged, and vehicle-treated mice; $\mathrm{Bt} / \mathrm{CAIO}$; $\mathrm{Bt} / \mathrm{CAI} 00 ; \mathrm{Bt} / \mathrm{CA} 200, \mathrm{Bt}-$ sensitized and 10,100 or $200 \mathrm{mg} / \mathrm{kg}$ of CA-treated mice, respectively; Bt/Dex3, Bt-sensitized and $3 \mathrm{mg} / \mathrm{kg}$ Dex-treated mice. Columns represent the mean values of the results obtained from five animals, and error bars represent the standard error from the means. \#\# $<0.00$ I vs control; $*^{* *} p<0.001$ vs $\mathrm{Bt}$ group.ANOVA-Tukey.

\section{Treatment with caffeic acid}

Caffeic acid (CA) or 3,4-Dihydroxycinnamic acid was purchased from Sigma-Aldrich. The different groups were treated orally and daily from the $8^{\text {th }}$ to the $14^{\text {th }}$ day of the experimental protocol, one hour after the intranasal challenges with 10,100 or $200 \mathrm{mg} / \mathrm{kg}$ of $\mathrm{CA}$, and/or with $3 \mathrm{mg} / \mathrm{kg}$ of Dexametazone (Dex) (Figure 1). The groups of animals were named as: Control, non-sensitized and salinetreated mice; $\mathrm{Bt}$, Bt-sensitized mice; $\mathrm{Bt} / \mathrm{CA}_{10} ; \mathrm{Bt} / \mathrm{CA}_{100} ; \mathrm{Bt} / \mathrm{CA}_{200}$, $\mathrm{Bt}-$ sensitized and 10,100 or $200 \mathrm{mg} / \mathrm{kg}$ of CA-treated mice, respectively; $\mathrm{Bt} /$ Dex, Bt-sensitized and Dex-treated mice.

\section{Bronchoalveolar Lavage (BAL) collection and cell counting}

The trachea was canulated and the lungs were carefully washed three times with $0.5 \mathrm{~mL}$ of phosphate buffered saline, $\mathrm{pH} 7.4$ (PBS) containing $1 \%$ of bovine serum albumin (BSA) (Sigma Aldrich $\left.{ }^{\circledR}\right)$. The total number of leukocytes in the BAL was immediately determined in a hemocytometer, using Trypan blue. Differential cell counts were obtained by using May-Grunwald-Giemsa - stained cytospin preparations. A differential count of at least 100 cells was made in a blind fashion in accordance with standard morphologic criteria.

\section{Eosinophil peroxidase (EPO) activity}

The EPO activity in the cells obtained from the BAL was measured according to a previously described method. ${ }^{26}$ Briefly, cell suspensions were frozen and thawed three times in liquid nitrogen. After centrifugation at $4^{\circ} \mathrm{C}$ for $10 \mathrm{~min}$ at $1000 \mathrm{~g}$, the cell lysates were placed into wells of 96 -well plates $(75 \mu \mathrm{L} /$ well), followed by the addition of $150 \mu \mathrm{L}$ of the chromogen and substrate solution $(1.5 \mathrm{mmol} / \mathrm{L}$ of o-phenylenediamine and $6.6 \mathrm{mmol} / \mathrm{L}$ of $\mathrm{H}_{2} \mathrm{O}_{2}$ in $0.05 \mathrm{~mol} / \mathrm{L}$ Tris- $\mathrm{HCl}$, 
$\mathrm{pH}$ 8.0). After $30 \mathrm{~min}$ at room temperature, the reaction was stopped with the addition of $75 \mu \mathrm{L}$ of $0.2 \mathrm{~mol} / \mathrm{L}$ citric acid, and the absorbance of the samples determined at $492 \mathrm{~nm}$ in an ELISA reader.

\section{Measurement of Bt-specific IgGI, IgG2a and IgE antibodies in serum}

Serum antibody levels were determined by ELISA using samples collected 24hours after the last Bt-challenge. In brief, wells of a 96well microtitre high-binding plate $\left(\operatorname{Costar}^{\mathbb{R}}\right)$ were coated with $\mathrm{Bt}$ $(100 \mu \mathrm{g} / \mathrm{mL})$ overnight, at $4^{\circ} \mathrm{C}$. The wells were washed 3 times with PBS containing $0.05 \%$ Tween 20 (PBS-T) and blocked during one hour with PBS-T containing 10\% fetal calf serum (FCS), at room temperature (RT). After several washes with PBS-T, the mouse sera were added and incubated overnight at $4^{\circ} \mathrm{C}$. After this incubation period and washes, a biotin-conjugated rat anti-mouse IgE, IgG1 or IgG2a (BD Pharmingen, San Diego, CA, USA) was added in each well and incubated during one hour at RT. A solution of avidinhorseradish peroxidase (BD Pharmingen, San Diego, CA, USA) was then added to each well during $30 \mathrm{~min}$. After washings, a solution containing 3,3',5,5'-tetramethylbenzidine and hydrogen peroxide was added and incubated during $30 \mathrm{~min}$ at RT and the reaction was stopped with $4 \mathrm{M}$ sulfuric acid.

\section{Lung histopathological analysis}

The degree of peribronchiolar and perivascular inflammation was evaluated as described previously. ${ }^{27}$ Briefly, lung tissues were fixed by inflation with freshly prepared $10 \%(\mathrm{v} / \mathrm{v})$ paraformaldehyde. The specimens were dehydrated and embedded in paraffin. Tissue sections $(5 \mu \mathrm{m})$ were stained with haematoxylin and eosin, for the assessment of cellular infiltration under optical microscopy with 200x magnification using the software Image-Pro Plus Version 7.0 (Media Cybernetics, San Diego, CA, USA). Additionally, tissue sections were stained with periodic acid-Schiff to assess mucus presence.

\section{Cytokines production on spleen cells culture}

Spleens were removed aseptically and teased to prepare a singlecell suspension. The splenocytes were incubated at $2.5 \times 106 \mathrm{cell} / \mathrm{s} / \mathrm{mL}$ in complete RPMI supplemented with $5 \%$ fetal bovine serum, $2 \mathrm{mM}$ glutamine, $50 \mathrm{mM}, 100 \mathrm{U} / \mathrm{mL}$ peni cillin and $1 \mu \mathrm{g} / \mathrm{mL}$ streptomycin medium. Following they were incubated with $5 \mu \mathrm{g} / \mathrm{mL}$ of PWM with or without CA at concentrations of 100,50 or $25 \mu \mathrm{M}$ for $72 \mathrm{~h}$ at $37^{\circ} \mathrm{C}$, $5 \% \mathrm{CO}_{2}$. After 72 hours of cultivation, the supernatants were collected and IL-13 and IL-5 levels were determined by ELISA as recommended by the manufacturer (BD Pharmingen, USA). Cell proliferation was estimated based on MTT-tetrazolium method.

\section{Statistical analysis}

The data normality was determined by the Kolmogorov-Smirnov test. The one-way analysis of variance (ANOVA) and Tukey's post-test have been applied to determine the statistical significance between the experimental groups. Differences in $p$ values $\leq 0.05$ were considered statistically significant. Each experiment was repeated at least two times.

\section{Results}

Treatment with caffeic acid (CA) reduces the Btinduced eosinophilia and eosinophil peroxidase (EPO) levels in BAL

To assess the effects of CA on the eosinophilic exudate in BAL of the Bt-sensitized and challenged mice, the presence of cells in the
BAL was assessed 24hours after the last challenge. Bt-challenged mice displayed a significant increase in total cells, eosinophils, and EPO activity when compared to the control group $(p<0.001)$ (Figure 1A- $1 \mathrm{C}$ ). Oral administration of 100 and $10 \mathrm{mg} / \mathrm{kg}$ of CA, daily and one hour after the Bt challenges, significantly suppressed the total inflammatory cells, the number of eosinophils and also decreased EPO activity, in relation to the untreated Bt-immunized and challenged mice $(p<0.001)$ (Figure 1A- 1C). Oral administration of $200 \mathrm{mg} / \mathrm{kg}$ of CA did not modify the number of total inflammatory cells and did not suppress the number of eosinophils while the treatment with $3 \mathrm{mg}$ / $\mathrm{kg}$ of Dex, suppressed total leukocytes, eosinophils and EPO activity in BAL. Treatment with caffeic acid (CA) ameliorates the
pathological changes in lungs of Bt-immunized animals

Inflammatory modifications of lung histology are illustrated in Figure 2A-2F. In the vehicle control mice, the airway and peribronchovascular space were essentially normal Figure $2 \mathrm{~A}$. In contrast the Bt-immunized mice group had significant influx of inflammatory cells Figure 2B. Treatment with 10 and $100 \mathrm{mg} / \mathrm{kg}$ of CA (Figure 2C) and (Figure 2D) respectively, and Dex (Figure 2F) markedly reduced the inflammatory cell infiltration within the peribronchiolar and perivascular regions. The administration of $200 \mathrm{mg} / \mathrm{kg}$ of CA (Figure 2E) did not modify the bronchial architecture compared to the Bt-immunized mice.
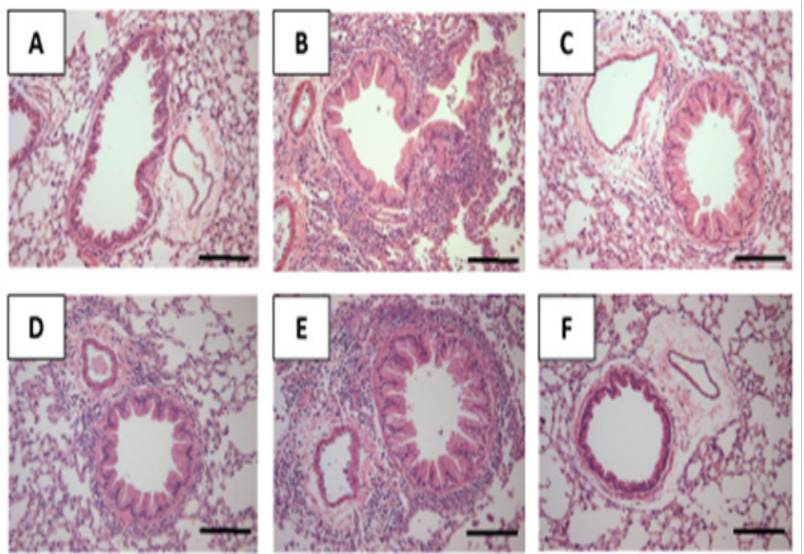

Figure 2 Effect of the treatment with caffeic acid (CA) on recruitment of leukocytes in lung tissues of mice sensitized with Blomia tropicalis extract $(\mathrm{Bt})$. Sections were stained with hematoxylin and eosin staining (magnification $\times 200$ ). (A) Lung section from a control, saline-treated mice (B) Lung section from a Bt- immunized and challenged, saline-treated mice (C) Lung section from a Bt-immunized and challenged, 10 (C), I00(D) and 200mg/ $\mathrm{kg}(\mathrm{E}) \mathrm{CA}$-treated mice (F) Lung section from a Bt-immunized and challenged, $3 \mathrm{mg} / \mathrm{kg}$ Dex-treated mice. Scale bar, $100 \mu \mathrm{m}$.

\section{Treatment with caffeic acid (CA) reduces the amount of mucus in the airways}

To evaluate airway hypersecretion of mucus and goblet-cell hyperplasia, we stained lung sections with PAS. Goblet-cell hyperplasia was significantly induced in the airway (mucus overproduction was clearly observed as a violet color) in Bt- immunized and challenged mice (Figure 3B), compared to the control group (Figure 3A). Treatment with 10 (Figure 3C) and 100mg/kg (Figure 3D) of CA and $3 \mathrm{mg} / \mathrm{kg}$ of Dex (Figure 3F) suppressed mucus hypersecretion in the lung tissue in relation to the untreated Bt-immunized and challenged mice. However, the oral treatment with $200 \mathrm{mg} / \mathrm{kg}$ of CA (Figure 3E) did not affect the architecture bronchial compared to the Btimmunized mice. 

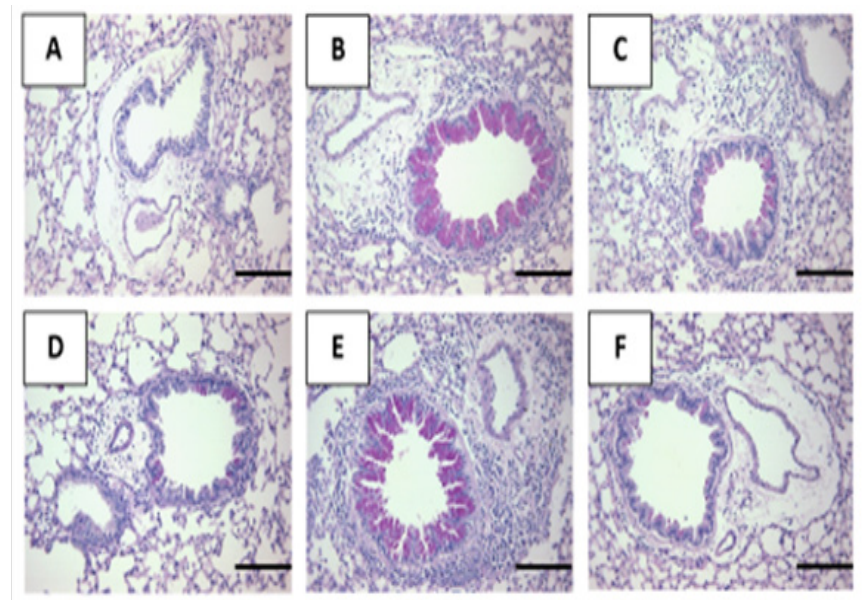

Figure 3 Effect of treatment with caffeic acid (CA) on the production of mucus in the lung tissue of mice sensitized with Blomia tropicalis extract $(B t)$. Sections were stained with periodic acid-Schiff (magnification $\times 200)$. (A) Lung section from a control, saline-treated mice (B) Lung section from a Btimmunized and challenged, saline-treated mice $(C)$ Lung section from a Btimmunized and challenged, I0 (C), 100 (D) and $200 \mathrm{mg} / \mathrm{kg}$ (E) CA-treated mice; (F) Lung section from a Bt-immunized and challenged, $3 \mathrm{mg} / \mathrm{kg}$ Dex-treated mice. Scale bar, $100 \mu \mathrm{m}$.

Treatment with caffeic acid (CA) does not change the levels of Bt-specific IgE antibodies in the sera of Btimmunized mice

The IgE concentration in serum was significantly increased in the Bt-sensitized and challenged mice compared to the control group (\#\#\#p<0.001); (Figure 4). However, the treatment with caffeic acid (CA) did not change the levels of Bt-specific IgE antibodies in the sera of Bt-immunized mice. Only the treatment with $3 \mathrm{mg} / \mathrm{kg}$ of Dex decreased serum IgE concentrations of Bt-immunized and challenged mice $(* * * p<0.001)$ (Figure 4).

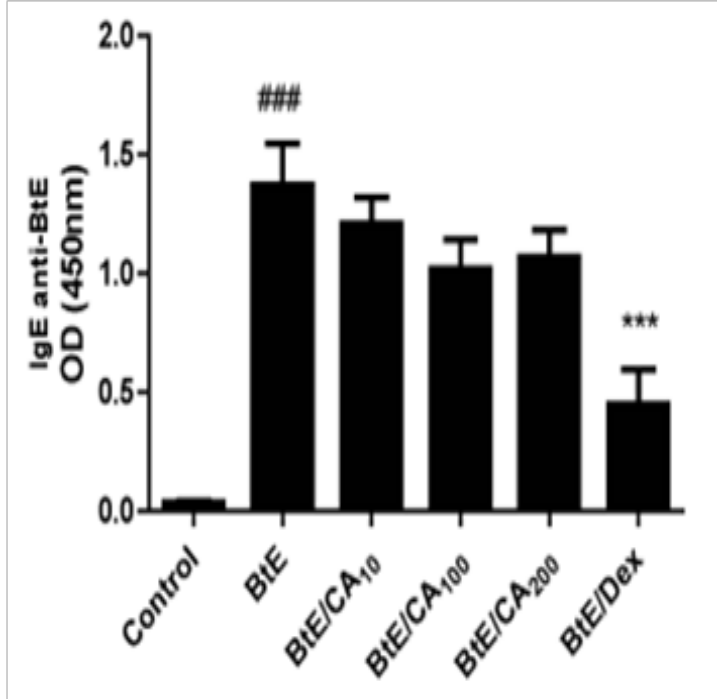

Figure 4 Levels of anti-Blomia tropicalis $(\mathrm{Bt}) \mathrm{lgE}$ antibodies in Bt-immunized mice and treated with caffeic acid (CA). Antibody levels were measured by indirect ELISA. Control, vehicle-treated animals; $\mathrm{Bt}$, Bt-sensitized and challenged, and vehicle-treated mice; Bt/CAI0; Bt/CAI00; Bt/CA200, Btsensitized and 10, 100 or $200 \mathrm{mg} / \mathrm{kg}$ of CA-treated mice, respectively; Bt/Dex3, Bt-sensitized and $3 \mathrm{mg} / \mathrm{kg}$ Dex-treated mice. Columns represent the mean values of the results obtained from five animals, and error bars represent the standard error from the means. \#\# $<0.00$ I vs control; $*^{* *} p<0.00$ I vs $B t$ group.ANOVA-Turkey.
Treatment with caffeic acid (CA) decreases the levels of Bt-specific IgG2a and does not change Bt-specific IgG I antibodies in the sera of Bt-immunized mice

Serum concentrations of Bt-specific IgG1 and IgG2a were measured. Bt sensitization and challenge elevated the levels of Btspecific $\operatorname{IgG} 1$ and $\operatorname{IgG} 2 \mathrm{a}(\mathrm{p}<0.001$; Figure $5 \mathrm{~A}$ and $* \mathrm{p}<0.05$; (Figure $5 \mathrm{~A})$ compared to control, but IgG1 seems to have much higher titers in this model (see O.D.). The administration of $100 \mathrm{mg} / \mathrm{kg}$ of CA and $3 \mathrm{mg} / \mathrm{kg}$ of Dex significantly lowered the levels of Bt-specific $\operatorname{IgG1}$ in relation to the untreated Bt-immunized and challenged mice $(\mathrm{p}<0.05 ; \mathrm{p}<0.001$, respectively); (Figure $5 \mathrm{~A})$. However, the treatment with caffeic acid (CA) did not change the levels of Bt-specific IgG1 antibodies in the sera of Bt-immunized mice (Figure 5B).
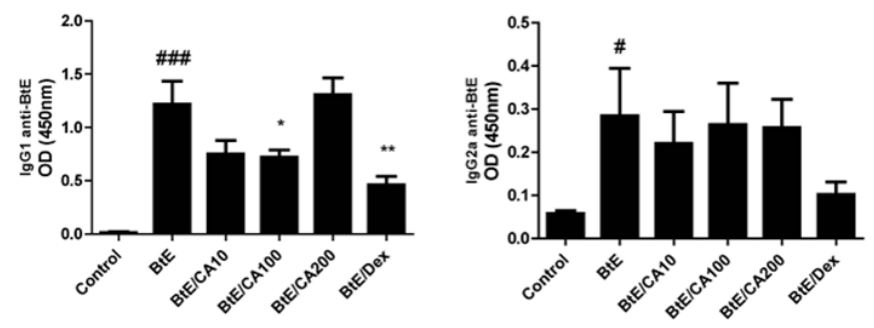

Figure 5A-5B Levels of anti-Blomia tropicalis (Bt) $\operatorname{lgE}$ antibodies in Btimmunized mice and treated with caffeic acid (CA). Antibody levels were measured by indirect ELISA. Control, vehicle-treated animals; Bt, Bt-sensitized and challenged, and vehicle-treated mice; $\mathrm{Bt} / \mathrm{CAIO}$; $\mathrm{Bt} / \mathrm{CAI} 00 ; \mathrm{Bt} / \mathrm{CA} 200, \mathrm{Bt}-$ sensitized and 10,100 or $200 \mathrm{mg} / \mathrm{kg}$ of CA-treated mice, respectively; Bt/Dex3, Bt-sensitized and $3 \mathrm{mg} / \mathrm{kg}$ Dex-treated mice. Columns represent the mean values of the results obtained from five animals, and error bars represent the standard error from the means. \#\# $<0.00$ I vs control; *** $p<0.00$ I vs $B t$ group.ANOVA-Turkey.

Treatment with caffeic acid (CA) reduces the levels of IL-4, IL-5 and IL-I 3 in spleen cells cultures

The cytokine profile was measured in the supernatants of spleen cells cultures. Our results have shown that PWM increased the levels of IL-4, IL -5 and IL-13 compared with control in culture (Figure 6A6C). CA decreased PWM-induced IL-4, IL -5 and IL-13 production at all concentrations ((Figure 6A-6C), but did not affect cell viability (data not shown).

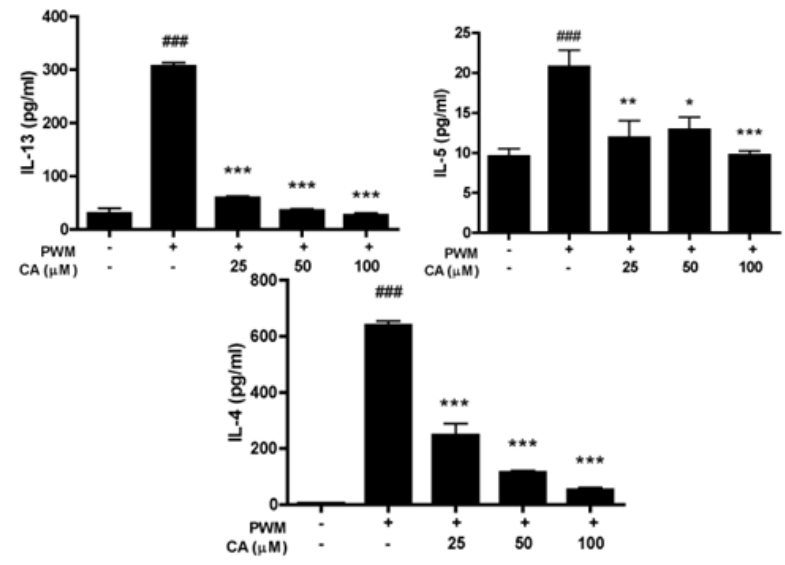

Figure 6A-6C Effect of caffeic acid (CA) on IL- I3, IL-5 and IL-4 production by cells stimulated with PWM. Spleen cells were incubated with $5 \mu \mathrm{g} / \mathrm{mL}$ of PWM with or without CA at concentrations of 100,50 or $25 \mu \mathrm{M}$. IL-I3, IL-5 and IL-4 quantification was done by sandwich ELISA. Columns represent the mean values of the results obtained from six animals, and error bars represent the standard error from the means. \#\# $<0.001$ vs control. ${ }^{*} p<0.05,{ }^{*}{ }_{p}<0.01$ and $* * * *_{p}<0.001$ vs Bt group. ANOVA-Turkey. 


\section{Discussion}

Asthma is an immune-mediated disorder characterized by airway hyperresponsiveness), eosinophilic airway inflammation and increased mucus secretion. T-helper type 2 (Th2) cells were dominant in the airways and Th2 cytokines such as IL-4, IL-5 and IL-13 play a pivotal role in the pathophysiology of asthma. ${ }^{28}$ Caffeic acid shows various biological properties, decreasing some inflammatory parameters, ${ }^{18}$ such as leukotriene biosynthesis inhibition ${ }^{20}$ and anti-asthmatic effects in guinea-pigs challenged with aerosolized ovalbumin. ${ }^{29}$ In this study, using a murine model of allergic airway disease induced by the sensitization to a common aeroallergen, the Blomia tropicalis mite extract, ${ }^{8}$ we demonstrated that the caffeic acid, a phenolic acid found in fruits and vegetables, significantly reduced the total inflammatory cells and the number of eosinophils, EPO activity, mucus secretion and serum Bt-specific IgG1 concentration. In vitro, CA demonstrated to decrease the production of IL-4, IL-5, and IL-13 in the supernatants of spleen cells cultures, indicating its effect in attenuating the Th2 inflammatory response.

The infiltration of lung inflammatory cells, especially of eosinophils, is indication of asthma inflammatory events and the severity of this disease is directly related to the degree of eosinophilia. ${ }^{30}$ Eosinophil recruitment, and their subsequent activation in the airways, is regulated mainly by IL -5 and IL-13, as well as chemokines and adhesion molecules such eotaxin. ${ }^{31}$ Infiltration of eosinophils into the airways is linked to the production of IL-5, which is important for eosinophil proliferation, activation, and migration, ${ }^{4}$ leading to the release of major basic protein, cysteinylleukotrienes, and eosinophil peroxidase that contributes to the lung tissue damage and airways hyper-reactivity. ${ }^{32}$ A previous study has shown that eosinophilic inflammation does not develop in the absence of IL-5. ${ }^{33}$ Eotaxin serves as an eosinophil chemoattractant and its prodution by airway epithelial cells is strongly increased by IL- $13 .{ }^{34}$ Our results showed that CA decreases number of leukocytes, number of eosinophils and levels of EPO in the bronchoalveolar lavage (BAL). These observations may be explained by the reduction in Th2 cytokines, IL-5 and IL -13, since CA treatment led to lower level these cytokines in vitro. Airway mucus hyper secretion associated with goblet cell hyperplasia and metaplasia is a common feature of asthma that can be assessed in murine airway disease models by histological analysis of the airway epithelium..$_{35}$ Studies have demonstrated that tissue inflammation, mucus hyper-production and goblet cell hyperplasia are induced by IL-13. ${ }^{36}$ Therefore, in the present study, caffeic acid inhibits production of IL-13 in splenocyte cultures, which would explain the reduction of mucus secretion in the lungs of treated mice. Previous studies have shown that neutralization of IL-13 inhibits mucus cell up regulation ${ }^{35}$ which corroborates our results.

Th2 cytokines, including IL-4, IL-5, and IL-13, have been demonstrated to play an important role in the pathogenesis of airway inflammation. ${ }^{31}$ IL-4 promotes the differentiation and proliferation of Th2-type T cells, and the switching of B cells to produce IgG1 and IgE iso types antibodies. ${ }^{37}$ In the present study, the serum level of Bt-specific IgG1 in Bt-sensitized mice was significantly reduced by administration of CA. The production of IL-4, from isolated splenocytes incubated in the presence of PWM, was remarkably inhibited by the addition of CA, and the modulation on IgG1 could be related the decrease in IL-4. The biological activities of IgE are mediated through high-affinity IgE receptors (FceRI) on mast cells and basophils. ${ }^{32}$ When allergens combine with $\operatorname{IgE}$ and mast cells, mast cells are activated and release histamine to cause severe allergic reactions. ${ }^{1}$ In the present study, our data have also shown no significance difference of Bt-specific IgE in Bt-sensitized mice treated with CA. We hypothesized that the CA can decrease the expression of FceRI receptors on mast cells or CA can bind to IgE receptors on mast cell, preventing degranulation and reducing inflammatory process, ${ }^{3} 8$ which explains the high levels of this immunoglobulin free in serum.

In summary, the administration of CA in this mouse asthma model significantly decreased the number of inflammatory cells, eosinophils and EPO in the bronchoalveolar lavage (BAL) and lung tissues. Furthermore, the modulation of IL-4, IL-5 and IL-13 may be related to CA anti-inflammatory activity in Bt models. The mechanism whereby CA modulate cytokine production and inflammation in $\mathrm{Bt}$ models is not completely elucidate and further studies aiming to disentangle these findings are needed. Our findings suggest that CA may effectively inhibit the progression of airway inflammation of allergic asthma.

\section{Acknowledgements}

The authors want to thank Brazilian agency CAPES for financial support and for Carneiro TCB scholarship.

\section{Conflict of interest}

The author declares no conflict of interest.

\section{References}

1. Huang WC and Liou CJ. Dietary acacetin reduces airway hyper responsiveness and eosinophil infiltration by modulating eotaxin-1 and th 2 cytokines in a mouse model of asthma. Evid Based Complement Alternat Med. 2012;2012:910520.

2. Mallol J, Crane J, von Mutius E, et al. The international study of asthma and allergies in childhood (isaac) phase three: A global synthesis. Allergol Immunopathol (Madr). 2013;41(2):73-85.

3. Siddiqui S, Morris J, Avery N, et al. Pulmonary eosinophilia correlates with allergen deposition to the lower respiratory tract in a mouse model of asthma. Clin Exp Allergy. 2008;38(8):1381-1390.

4. Lee MY, Lee NH, Jung D, et al. Protective effects of allantoin against ovalbumin (ova)-induced lung inflammation in a murine model of asthma. Int Immunopharmacol. 2010;10(4):474-80.

5. Pacífico LG, Marinho FA, Fonseca CT, et al. Schistosoma mansoni antigens modulate experimental allergic asthma in a murine model:A major role for $\mathrm{cd} 4+\mathrm{cd} 25+$ foxp $3+\mathrm{t}$ cells independent of interleukin-10. Infect Immun. 2009;77(1):98-107.

6. Sousa S, Fraga J, Martins Vn, et al. Sensibilização a ácaros num grupo de crianças atópicas do interior norte de portugal. Capa. 2010;41(5)

7. Sade K, Roitman D and Kivity S. Sensitization to dermatophagoides, blomia tropicalis, and other mites in atopic patients. $J$ Asthma. 2010;47(8):849-852.

8. Baqueiro T, Russo M, Silva VM, et al. Respiratory allergy to blomia tropicalis: Immune response in four syngeneic mouse strains and assessment of a low allergen-dose, short-term experimental model. Respir Res. 2010;11:51.

9. Lee M, Kim S, Kwon OK, et al. Anti-inflammatory and anti-asthmatic effects of resveratrol, a polyphenolic stilbene, in a mouse model of allergic asthma. Int Immunopharmacol. 2009;9(4):418-24.

10. Barnes PJ. New therapies for asthma. Trends Mol Med.2006;12(11):515520 . 
11. Wu CH, Huang HW, Lin JA, et al. The proglycation effect of caffeic acid leads to the elevation of oxidative stress and inflammation in monocytes, macrophages and vascular endothelial cells. J Nutr Biochem. 2011;22(6):585-594.

12. Olthof MR, Hollman PC, Katan MB. Chlorogenic acid and caffeic acid are absorbed in humans. $J$ Nutr. 2001;131(1):66-71.

13. Sato Y, Itagaki S, Kurokawa T, et al. In vitro and in vivo antioxidant properties of chlorogenic acid and caffeic acid. Int J Pharm. 2011;403(12):136-138.

14. Ye Z, Hong CO, Lee $\mathrm{K}$, et al. Plasma caffeic acid is associated with statistical clustering of the anticolitic efficacy of caffeic acid in dextran sulfate sodium-treated mice. J Nutr. 2011;141(11):1989-1995.

15. Ye Z, Liu Z, Henderson A, et al. Increased cyp4b1 mrna is associated with the inhibition of dextran sulfate sodium-induced colitis by caffeic acid in mice. Exp Biol Med (Maywood). 2009;234(6):605-616.

16. de Campos Buzzi F, Franzoi CL, Antonini G, et al. Antinociceptive properties of caffeic acid derivatives in mice. Eur J Med Chem. 2009;44(11):4596-4602.

17. Mehrotra A, Shanbhag R, Chamallamudi MR, et al. Ameliorative effect of caffeic acid against inflammatory pain in rodents. Eur J Pharmacol. 2011;666(1-3):80-86.

18. Chao CY, Mong MC, Chan KC, et al. Anti-glycative and anti-inflammatory effects of caffeic acid and ellagic acid in kidney of diabetic mice. Mol Nutr Food Res. 2010;54(3):388-395.

19. Hossen MA, Inoue T, Shinmei Y, et al. Caffeic acid inhibits compound 48/80-induced allergic symptoms in mice. Biol Pharm Bull. 2006;29(1):64-66.

20. Koshihara Y, Neichi T, Murota S, et al. Caffeic acid is a selective inhibitor for leukotriene biosynthesis. Biochim Biophys Acta. 1984;792(1):9297.

21. Kim SR, Jung YR, Kim DH, et al. Caffeic acid regulates lps-induced $\mathrm{NF}-\kappa \mathrm{B}$ activation through $\mathrm{NIK} / \mathrm{IKK}$ and $\mathrm{c}-\mathrm{Src} / \mathrm{ERK}$ signaling pathways in endothelial cells. Arch Pharm Res. 2014;37(4):539-547.

22. Yang WS, Jeong D, Yi YS, et al. IRAK1/4-targeted anti-inflammatory action of caffeic acid. Mediators Inflamm; 2013.

23. Búfalo MC, Ferreira I, Costa G, et al. Propolis and its constituent caffeic acid suppress LPS-stimulated pro-inflammatory response by blocking $\mathrm{NF}-\kappa \mathrm{B}$ and MAPK activation in macrophages. J Ethnopharmacol. 2013;149(1):84-92.

24. Costa RS, Carneiro TC, Cerqueira-Lima AT, et al. Ocimum gratissimum linn. And rosmarinic acid, attenuate eosinophilic airway inflammation in an experimental model of respiratory allergy to blomia tropicalis. Int Immunopharmacol. 2012;13(1):126-134.

25. Lowry Oh, Rosebrough Nj, Farr Al, et al. Protein measurement with the folin phenol reagent. J Biol Chem. 1951;193(1):265-275.
26. Choi JR, Lee CM, Jung ID, et al. Apigenin protects ovalbumin-induced asthma through the regulation of gata-3 gene. Int Immunopharmacol. 2009;9(7-8):918-924.

27. Takano H, Osakabe N, Sanbongi C, et al. Extract of perilla frutescens enriched for rosmarinic acid, a polyphenolic phytochemical, inhibits seasonal allergic rhinoconjunctivitis in humans. Exp Biol Med (Maywood). 2004;229(3):247-254.

28. Park HJ, Lee CM, Jung ID, et al. Quercetin regulates th1/th2 balance in a murine model of asthma. Int Immunopharmacol. 2009;9(3):261-267.

29. Lee JY, Lee JG, Sim SS, et al. Anti-asthmatic effects of phenylpropanoid glycosides from clerodendron trichotomum leaves and rumex gmelini herbes in conscious guinea-pigs challenged with aerosolized ovalbumin. Phytomedicine. 2011;18(2-3):134-142.

30. Xiong YY, Wu FH, Wang JS, et al. Attenuation of airway hyperreactivity and thelper cell type 2 responses by coumarins from peucedanum praeruptorum dunn in a murine model of allergic airway inflammation. J Ethnopharmacol. 2012;141(1):314-321.

31. El Gazzar M, El Mezayen R, Marecki JC, et al. Anti-inflammatory effect of thymoquinone in a mouse model of allergic lung inflammation. Int Immunopharmacol. 2006;6(7):1135-1142.

32. Lee KS, Lee HK, Hayflick JS, et al. Inhibition of phosphoinositide 3-kinase delta attenuates allergic airway inflammation and hyperresponsiveness in murine asthma model. FASEB J. 2006;20(3):455-465.

33. Foster PS, Hogan SP, Ramsay AJ, et al. Interleukin 5 deficiency abolishes eosinophilia, airways hyperreactivity, and lung damage in a mouse asthma model. J Exp Med. 1996;183(1):195-201.

34. Li L, Xia Y, Nguyen A, et al. Effects of th2 cytokines on chemokine expression in the lung:Il-13 potently induces eotaxin expression by airway epithelial cells. J Immunol. 1999;162(5):2477-2287.

35. Tomlinson KL, Davies GC, Sutton DJ, et al. Neutralisation of interleukin-13 in mice prevents airway pathology caused by chronic exposure to house dust mite. PLoS One. 2010;5(10):pii:e13136.

36. Zhu Z, Homer RJ, Wang Z, et al. Pulmonary expression of interleukin-13 causes inflammation, mucus hypersecretion, subepithelial fibrosis, physiologic abnormalities, and eotaxin production. J Clin Invest. 1999;103(6):779-788.

37. Lee MY, Shin IS, Lim HS, et al. A water extract of samchulkunbi-tang attenuates airway inflammation by inhibiting inos and mmp-9 activities in an ovalbumin-induced murine asthma model. BMC Complement Altern Med. 2012;12:257.

38. Yamaguchi M, Hirai K, Komiya A, et al. Regulation of mouse mast cell surface Fc epsilon RI expression by dexamethasone. International immunology. 2001;13(7):843-851. 